\title{
Hannah Arendt as a Theorist of International Criminal Law
}

David Luban

Georgetown University Law Center, luband@law.georgetown.edu

Georgetown Public Law and Legal Theory Research Paper No. 11-30

This paper can be downloaded free of charge from:

https://scholarship.law.georgetown.edu/facpub/619

http://ssrn.com/abstract $=1797780$

Int'I Crim. L. Rev. (forthcoming)

This open-access article is brought to you by the Georgetown Law Library. Posted with permission of the author. Follow this and additional works at: https://scholarship.law.georgetown.edu/facpub

Part of the Criminal Law Commons, International Law Commons, and the Jurisprudence Commons 


\title{
HANNAH ARENDT AS A THEORIST OF INTERNATIONAL CRIMINAL LAW
}

\author{
David Luban * \\ Forthcoming, symposium on “Women and International Criminal Law," International \\ Criminal Law Review
}

Hannah Arendt had no legal training, and before 1960 her writings display little interest in law or legal institutions. ${ }^{1}$ Then Israeli agents kidnapped Adolf Eichmann in Argentina and brought him to Jerusalem to stand trial for the crimes of the Holocaust. In June 1960, Arendt wrote to Mary McCarthy, "I am half toying with the idea to get some magazine to send me to cover the Eichmann trial. Am very tempted.”2 Arendt approached William Shawn, editor of The New Yorker. A bit diffidently, Shawn accepted her offer. ${ }^{3}$ Her friend and mentor, the philosopher Karl Jaspers, was skeptical: "The political realm is of an importance that cannot be captured in legal terms (the attempt to do so is Anglo-Saxon and a self-deception ....).”4 To which Arendt replied:

I ... admit that as far as the role of the law is concerned, I have been infected by the Anglo-Saxon influence. But quite apart from that, it seems to me to be in the nature of this case that we have no tools to hand except legal ones with which we have to judge and

\footnotetext{
* University Professor and Professor of Law and Philosophy, Georgetown University Law Center. I am grateful to Diane Marie Amann, Gabriella Blum, Neha Jain, Anthony Lang, Peter Margulies, Allegra Macleod, and Beth Van Schaack for comments on an earlier draft.

${ }^{1}$ For example, the half-dozen passages indexed under the word "law" in her philosophical masterpiece, The Human Condition (University of Chicago Press, Chicago,1958), are casual and undeveloped. All are brief statements of the idea that the law sets the boundaries within which a community's political life can unfold, but none examines whatever implications follow for the nature of laws or legal institutions.

${ }^{2}$ Hannah Arendt to Mary McCarthy, June 20, 1960, in Carol Brightman (ed.), Between Friends: The Correspondence of Hannah Arendt and Mary McCarthy 1949-1975 (Harcourt Brace, New York, 1995) p. 81.

${ }^{3}$ Arendt to McCarthy, Oct. 8, 1960, Brightman, supra note 2, pp. 98-99; cf. Elisabeth Young-Bruehl, Hannah Arendt: For Love of the World (Yale University Press, New Haven,1982) p. 328.

${ }^{4}$ Karl Jaspers to Hannah Arendt, Dec. 16, 1960, in Lotte Kohler \& Hans Saner (eds.), Robert \& Rita Kimber (trans.), Hannah Arendt-Karl Jaspers Correspondence 1926-1969 (Mariner Books, New York, 1992) p. 413.
} 
pass sentence on something that cannot even be adequately represented either in legal terms or in political terms. That is precisely what makes the process itself, namely, the trial, so exciting. The question is: Would things be different if we had a law against hostes humani generis and not only against murderers and similar criminals? ${ }^{5}$

Arendt republished the resulting five-part New Yorker article in the 1963 book Eichmann in Jerusalem: A Report on the Banality of Evil. It became her most famous work, and by $2006 E J$ (as I shall refer to it for short) had sold almost 300,000 copies. ${ }^{6}$

$E J$ contains a densely argued epilogue and postscript that discuss important legal questions about jurisdiction and mens rea. Her thoughts about jurisdiction were partly worked out even before the trial began, in a fascinating exchange of letters between her and Jaspers, debating the merits of what today we would call truth commissions, the International Criminal Court, and universal jurisdiction. EJ fiercely defends the proposition that trials of international crimes must concern themselves solely with justice, with no ulterior political agenda. The mens rea discussion grows from her most famous concept in $E J$, the "the banality of evil." EJ also analyzes the special character of the crime of genocide. Arendt's ideas are of great pertinence to students of international criminal law, and this article aims to develop them as they unfold from more fundamental themes in Arendt's thought.

\footnotetext{
${ }^{5}$ Arendt to Jaspers, Dec. 23, 1960, in Kohler \& Sahner, supra note 4, p. 417.

${ }^{6}$ Hannah Arendt, Eichmann in Jerusalem: A Report on the Banality of Evil, revised ed., (Penguin Classics, New York, 1964). On the number of copies sold, Amos Elon, The Excommunication of Hannah Arendt, $<$ http://us.penguingroup.com/static/html/classics/essays/eichmann.html> (visited July 21, 2010). Arendt revised $E J$ in 1964, adding a new postscript responding to her critics, and it is to this edition that I refer throughout this article.

$E J$ aroused a ferocious controversy, but that is mostly not my subject in this article. For discussion of the "Eichmann controversy," see Young-Bruehl, supra note 2, at 347-66; David Laskin, Partisans: Marriage, Politics, and Betrayal Among the New York Intellectuals (Simon and Schuster, New York, 2000) pp. 238-44, 248-49.
} 
Arendt's generic label for the subject matter of international criminal law is “crimes against humanity,” because (like Jaspers) she believed that crimes become international only when they offend all of humanity. ${ }^{7}$ Her usage, obviously, bears little relation to standard legal terminology, in which "crime against humanity" is not the generic name for international crimes, but rather the specific name of one category of international crimes, alongside the other core crimes of aggression, war crimes, and genocide. "Core crimes" is the closest we get to a generic label for all of them. Making matters more confusing, in EJ Arendt treats the term “crime against humanity” as a nearsynonym for "genocide," and she completely ignores the legal definitions in the Convention on Genocide and the Nuremberg Charter. ${ }^{9}$ She considered genocide to be the paradigm crime against humanity, not as defined in law but in the literal sense conveyed by the words themselves: a crime that offends all humanity.

Arendt's unconventional use of conventional terminology may annoy legal readers and convince them that $E J$ is legally naive. That would be unfortunate. In my view, no theorist has thought more perceptively than Arendt about the basis of

\footnotetext{
${ }^{7}$ Jaspers: "This case concerns all of humanity.” Jaspers to Arendt, Dec. 16, 1960, in Kohler \& Sahner, supra note 4, p. 413. Arendt: "The concept of hostis humani generis-however one translates it, but not: crime against humanness; but rather, against humanity—is more or less indispensable to the trial....I think we are in basic agreement on these points....” Arendt to Jaspers, Feb. 5, 1961, in Kohler \& Sahner, supra note 4, p. 423.

${ }^{8}$ Diane Marie Amann has pointed out to me that the French criminal code classifies genocide side by side with “autres crimes contre l'humanité" within a title labeled "Des crimes contre l'humanité.” France, Code Pénal, Livre II, titre Ier, sous-titre Ier, $<$ http://www.legifrance.gouv.fr/affichCode.do?cidTexte=LEGITEXT000006070719\&dateTexte=2010092> (visited Oct. 15, 2010). Arendt's usage may well seem less unconventional to francophone jurists.

${ }^{9}$ She likewise ignores war crimes and the crime of aggression, perhaps because they played almost no role in the Eichmann case. Eichmann was not charged with aggression and only one of the fifteen counts of the indictment against him was for a war crime, namely "the persecution, expulsion and murder of the Jewish population of the countries occupied by the Germans and the other countries of the Axis, ... in the course of fulfilling his functions as specified in the First Count.” Prosecutor v. Eichmann Indictment, Eighth Count, <http://www.nizkor.org/hweb/people/e/eichmann-adolf/transcripts/Sessions/Session-001-02.html> (visited July 23, 2010). In other words, Eichmann's war crimes were factually indistinguishable from genocide.
} 
international criminal liability in mass atrocities, when thousands of perpetrators commit acts that we label "manifestly unlawful," without considering how thoroughly our label begs the question of why it wasn't manifest to the perpetrators.

\section{I. "The Challenge of the Unprecedented"}

Why did Arendt think that Eichmann's crimes “cannot even be adequately represented either in legal terms or in political terms," as she put it to Jaspers in the letter quoted above? For Arendt, the fundamental fact about the modern crime of genocide is the same as the fundamental fact about European totalitarianism: both confound the usual categories we use to make sense of moral, legal, and political life. In The Origins of Totalitarianism she castigates political science for "denying the outrageous, deducing the unprecedented from precedents, ... explaining phenomena by such analogies and generalities that the impact of reality and the shock of experience are no longer felt.”10 Arendt leveled a similar complaint against the legalisms of the Israeli court, which in her view "never rose to the challenge of the unprecedented ..., [but rather] buried the proceedings under a flood of precedents ....”11

To take one central example, we find Arendt asserting that legal discussions of the act of state defense "gave the illusion that the altogether unprecedented could be judged according to precedents ...."12 The traditional act of state defense rests on a conception of raison d'état grounded in political necessity. "In a normal political and legal system, such

\footnotetext{
${ }^{10}$ Hannah Arendt, The Origins of Totalitarianism, $2^{\text {nd }}$ ed., (Meridian, New York,1958) p. viii. I discuss Arendt's ideas about explanation in politics in David Luban, 'Hannah Arendt and the Primacy of Narrative', in Legal Modernism (University of Michigan Press, Ann Arbor,1994) p. 179, a revision of Luban, 'Explaining Dark Times: Hannah Arendt's Theory of Theory', 50 Social Research (1983) 215-48.

${ }^{11}$ Arendt, supra note 6, p. 263.

${ }^{12}$ Arendt, supra note 6, p. 134.
} 
crimes occur as an exception to the rule .... However ... in a state founded upon criminal principles, the situation is reversed." ${ }^{13}$ Law becomes crime and crime becomes law. ${ }^{14}$ Under such circumstances, non-criminal acts, like Himmler’s 1944 order to halt the genocide, "become a concession to necessity," 15 while crime becomes a matter of duty that loses "the quality by which most people recognize it — the quality of temptation."16 In other words, a criminal state turns the moral and legal universe upside-down, which is why an Eichmann, "who is in actual fact hostis generis humani, commits his crimes under circumstances that make it well-nigh impossible for him to know or to feel that he is doing wrong.” ${ }^{17}$ To Arendt these circumstances signaled "the totality of the moral collapse the Nazis caused in respectable European society—not only in Germany, but in almost all countries ....”18 Legal precedents from normal polities offer illusory guidance when a criminal regime turns the background morality of society upside down. That is why the Jerusalem judges, "too good, and perhaps also too conscious of the very foundations of their profession ... missed the greatest moral and even legal challenge of the whole case," namely that "under the conditions of the Third Reich only 'exceptions' could be expected to act 'normally.",19

In reconstructing this argument I have quoted Arendt's own language liberally, in part to exhibit stylistic features that enraged EJ's critics, namely her superior tone and her love affair with paradoxes. Her paradoxes, in the eyes of her critics, led her to minimize Eichmann’s individual culpability, defying respectable common sense. (As I shall show

\footnotetext{
${ }^{13}$ Ibid., p. 291.

${ }^{14}$ Ibid., p. 292; see also p. 148.

${ }^{15}$ Ibid., p. 291.

${ }^{16}$ Ibid., p. 150.

${ }^{17}$ Ibid., p. 276.

${ }^{18}$ Ibid., p. 125-26.

${ }^{19}$ Ibid., p. 26-27.
} 
later, this completely misunderstands Arendt's position, which is not to minimize his culpability but to rest it on something other than subjective mens rea.) Attributing Eichmann's baffling lack of conscience to the moral collapse of his society spoils the morality play of the criminal trial, in which a tribunal representing decent people isolates, condemns, and purges the cancer cells, the deviants. In Arendt's retelling, it turns out that decent people might not be so decent because criminals might not be so deviant. Organizers of tribunals stage their morality plays in order to spare us the need for acknowledging how normal some great criminals really were.

Arendt strongly believed that international criminal trials must never be staged as morality plays, or for any other ulterior political reasons. "I held and hold the opinion that this trial had to take place in the interests of justice and nothing else.”20 That required, for example, excluding general evidence about the Holocaust or the sufferings of the Jews unless it directly implicated Eichmann, and rejecting efforts to structure the trial to teach political "lessons" either to the Israeli public or the world at large. One of Arendt's major conclusions in $E J$ is that although focusing the trial on the Holocaust rather than on Eichmann was indeed Ben Gurion's goal and that of the prosecutor (who Arendt describes in scornful terms), the judges mostly succeeded in preventing this from happening. ${ }^{21}$ Her justice-centered view contrasts with that of writers who emphasize the political, didactic aims of international criminal trials within the larger project of post-

20 Ibid., p. 286.

${ }^{21}$ Ibid., p. 3-10. On the limited role of a court of law and its inadequacy to address large historical questions, see the court's well-taken reflections in Prosecutor v. Eichmann, Criminal Case No. 40/61, Judgment (Dist. Ct. Jerusalem 1961), paras.1-2. Arendt's venom against prosecutor Gideon Hausner is unmistakable; unfortunately, at least some of it seems to come from her German Jewish stereotypes of Ostjuden and "oriental” Jews. See Arendt to Heinrich Blücher, April 15, 1961, in Lotte Kohler (ed.), Peter Constantine (trans.), Within Four Walls: The Correspondence between Hannah Arendt and Heinrich Blücher 1936-1968 (Houghton Mifflin Harcout, Boston, 2000) p. 354. 
conflict peacemaking. In her view, the exclusive focus on the guilt or innocence of defendants, rather than on teaching the public about the horrors of the Holocaust, is essential so that "all the cogs in the machinery, no matter how insignificant, are in court forthwith transformed back into perpetrators, that is to say, into human beings." ${ }^{22}$ This is how she avoids the danger of minimizing Eichmann’s culpability.

\section{The World Turned Upside Down}

Europe’s moral collapse forms the subject of Arendt's first major book, the monumental The Origins of Totalitarianism (1951). She describes three linked phenomena of the nineteenth and early twentieth century. First was the rise of imperialism, especially in Africa, where European states for the first time committed bureaucratized mass murder grounded in racist ideology. Second was the dissolution of the old European class system, which left in its wake masses of "superfluous" individuals who could readily be mobilized into the totalitarian movements. (In EJ Arendt memorably describes the young Eichmann, discontentedly drifting from job to mediocre job, as a "leaf in the whirlwind of time, ... blown ... into the marching columns of the Thousand-Year Reich.”23) Third was the decline of the system of European nation-states, as nationalism, confronted after World War I by refugees and ethnic minorities, warped into a lethal compound of pseudo-science and ethnic fantasy. (Arendt notes that Soviet Marxism was layered on top of pan-Slavism, so that its supposed internationalism actually took the form of an ethnic imperialism not much different from that of Hitler.) Under the pressures of inflation, unemployment, and civil wars, political structures that

\footnotetext{
${ }^{22}$ Arendt, supra note 6, p. 289.

${ }^{23}$ Ibid., pp. 32-33.
} 
had allowed ethnic groups to lead a common life within territorial states collapsed. As these structures disintegrated, respect for human rights disintegrated with them, and entire groups were officially dehumanized and removed from the protection of law, the first step toward mass extermination. Elites allied themselves with the mob in their "justified disgust ... with the outlook and moral standards of the bourgeoisie." ${ }^{24}$ What these intellectuals failed to realize was that their supposed unmasking of bourgeois morality as a hypocritical cover for crime would be taken literally by totalitarian rulers, who declared crime to be a duty and decency to be a crime.

With the declaration that entire races or classes are mortal enemies, the root conception of humanism — that all human beings belong to a shared commonwealth (an idea that goes back to the Stoics)—disappears. Carl Schmitt perfectly expresses this point of view in his cynical slogan, "whoever invokes humanity wants to cheat." ${ }^{25}$ Instead of humanity, there is only us and them, friend and enemy, and the destruction of the enemy is the ultimate meaning of politics. In Arendt's diagnosis, precisely this outlook paved the way to crimes against humanity in a very literal sense. As she put it in an imaginary sentencing speech that the Jerusalem court might have delivered to Eichmann:

\footnotetext{
“[J]ust as you supported and carried out a policy of not wanting to share the earth with the Jewish people and the people of a number of other nations_as though you and your superiors had any right to determine who should and who should not inhabit the world-
}

\footnotetext{
${ }^{24}$ Arendt, supra note 10, p. 328. For her philosophical discussion of this phenomenon, see Arendt, 'Thinking and Moral Considerations', in Jerome Kohn (ed)., Responsibility and Judgment (Schocken, New York, 2003) pp. 176-78.

${ }^{25}$ Carl Schmitt, The Concept of the Political, George Schwab (trans.), (University of Chicago Press, Chicago,1996) p. 54.
} 
we find that no one, that is, no member of the human race, can be expected to want to share the earth with you. This is the reason, and the only reason, you must hang."26

Arendt's curiously fussy phrase "no one, that is, no member of the human race" underlines how strongly she believed the community that was judging Eichmann to consist of all human beings everywhere. The "crime against humanity" is, quite simply, the unwillingness to share the earth with all the peoples who inhabit it.

It might be objected that even if Arendt's genealogy of totalitarianism is accurate, it is too closely tied to Europe in the mid-twentieth century to be of use to contemporary international criminal law. This objection is mistaken. Arendt's most important point concerns the reversal of deviance and normality, of rule and exception, that creates the condition for mass atrocity. Even if the historical pathway to the inversion was very different in 1994 Rwanda than in 1942 Germany, the inversion itself is crucial for understanding both genocides_-and for understanding why normal legal categories might offer a poor lens through which to view perpetrators. The inversion is hardly unique to Europe between the wars. ${ }^{27}$ Whenever a state invokes emergency powers in the face of a real or imagined existential threat, it stands on the brink of inverting rule and exception; this is the meaning of Schmitt's famous aphorism "Sovereign is he who decides on the exception” ${ }^{28}$ — for, after all, in a normal state, the sovereign is he who decides on the rules.

\footnotetext{
${ }^{26}$ Arendt, supra note 6, p. 279.

${ }^{27}$ The inversion of normality and decency during periods in which people commit mass atrocity is a major theme of Mark Drumbl's recent book Atrocity, Punishment, and International Law (Cambridge University Press, Cambridge, 2007), a book that draws heavily on Arendt's observation.

${ }^{28}$ Carl Schmitt, Political Theology: Four Chapters on the Concept of Sovereignty, George Schwab (trans.), (University of Chicago Press, Chicago, 2006) p. 5.
} 


\section{Jurisdiction and "Humanity”}

Jaspers objected to Israel trying Eichmann because "[t]his case concerns all

humanity ...."29 He proposed

a foolishly simplistic idea: It would be wonderful to do without the trial altogether and make it instead a process of examination and clarification. The goal would be the best possible objectification of the historical facts. The end result would not be the judges' sentence, but certainty about the facts, to the extent such certainty can be attained. ${ }^{30}$

In other words, Jaspers wanted a truth commission, because the world lacks "a court that, as a representative of humanity, is competent to judge a crime against humanity ....”31

For that reason, he proposed turning Eichmann and the evidence over to the United Nations, although he was sure that "[t]he UN would cite legal objections to wriggle out of this situation.”32

Arendt disagreed with the truth commission proposal, and anticipated arguments that would eventually be made on behalf of the ICC and universal jurisdiction:

The only possibility seems to be to attach to the International Court at The Hague a criminal court for hostes generis humani that would be competent to try individuals regardless of nationality. As long as such a court does not exist, international law holds

\footnotetext{
${ }^{29}$ Jaspers to Arendt, Dec. 16, 1960, in Kohler and Saner, supra note 4, p. 413. He also fretted that "Israel may come away from it looking bad no matter how objective the conduct of the trial." Jaspers to Arendt, Dec. 12, 1960, p. 410; see also Jaspers to Arendt, Dec. 16, 1960, p. 413 ("Judgments passed by the victors on the vanquished have, in the past, been regarded as political actions and distinct from legal ones.”) Arendt too worried that the trial might become politicized. Arendt to Jaspers, Dec. 23, 1960, p. 416.

${ }^{30}$ Jaspers to Arendt, Dec. 16, 1960, ibid., p. 413. He repeats this "utopian suggestion” in his letter of Jan. 3, 1961, p. 420, and again in his letter of Feb. 14, 1961, where he calls it a "simpleminded fantasy," p. 424.

${ }^{31}$ Jaspers to Arendt, Feb. 14, 1961, ibid., p. 424.

32 Jaspers to Arendt, Dec. 16, 1960, ibid., p. 413.
} 
that any court in the world is competent—so why not Israel? Legally, Israel couldn't even claim it isn’t competent. ${ }^{33}$

She adds: “Don’t misunderstand me: I would be all in favor of an international court with appropriate powers.”34 In its absence, Israel could legitimately seize and try Eichmann because he was “an outlaw—a hostis generis humanis, the way pirates used to be.”35

In the same letter, she cites the passive personality principle as another basis for Israel to try Eichmann. By the time she wrote EJ, though, she came to doubt her earlier jurisdictional arguments. She rejects passive personality because it "unfortunately implies that criminal proceedings are initiated by the government in the name of the victims.”36 This blurs an essential difference between a civil and criminal proceeding. The former rectifies injuries to a victim, while the latter concerns injuries to the entire community, inflicted on the victim—in this case “a crime against humanity, perpetrated on the body of the Jewish people” rather than a crime against the Jewish people. ${ }^{37}$

This argument against passive personality is subtle and plausible. Her argument against universal jurisdiction is less compelling. A few weeks after her first letter about jurisdiction, she writes to Jaspers, “My pirate theory won’t do.” ${ }^{38}$ Pirates by definition are private actors, which would make piracy solely a crime against the victims. Employing the same reasoning she used to reject passive personality, she rejects the pirate analogy:

\footnotetext{
${ }^{33}$ Arendt to Jaspers, Dec. 23, 1960, ibid., p. 416.

34 Ibid.

${ }^{35}$ Id. at 414.

${ }^{36}$ Arendt, supra note 6, p. 260.

${ }^{37}$ Ibid., p. 269; see also pp. 7, 261. Eichmann was indicted under an Israeli statute concerning crimes against the Jewish people, but the statute gives this term a legal definition adapted from the definitions of genocide and the crime of genocide in the Convention on Genocide.

${ }^{38}$ Arendt to Jaspers, Feb. 5, 1961, in Kohler and Saner, supra note 4, p. 423.
} 
"although the crime at issue was committed primarily against the Jews, it is in no way

limited to the Jews or the Jewish question.”39

In my view, Arendt was too fixated on the historical connection between the concept of hostis generis humanis and piracy. ${ }^{40}$ Curiously, it is now she rather than the court that seems overly attached to precedent, wrongly rejecting her initial insight that horrific crimes can offend all humanity and therefore can justify universal criminal jurisdiction even though they have nothing to do with piracy. This seems like mere failure of imagination on her part. ${ }^{41}$ In $E J$ she rejects the "analogy between genocide and piracy” because the Genocide Convention rejected universal jurisdiction. ${ }^{42}$ This is a surprisingly formalist argument; in fact it was one of the defense arguments in the Eichmann trial. The Israeli court had a wholly adequate rejoinder, which Arendt overlooked: the Genocide Convention sets territoriality as the minimum requirement for genocide jurisdiction, but nothing prevents states from establishing other forms of jurisdiction in addition. ${ }^{43}$

Having rejected passive personality and universal jurisdiction, Arendt proposed her own alternative, which is far more eccentric:

\footnotetext{
${ }^{39}$ Ibid.

${ }^{40}$ It comes from Cicero, who asserted in De Officiis that "a pirate is not included in the number of lawful enemies, but is the common foe of all the world [communis hostis omnium]." Marcus Tullius Cicero, On Duties, Walter Miller (trans.), (Loeb Classical Library, Cambridge, MA, 1913), p. 385, III.xxix.107.

${ }^{41}$ Furthermore, she ignores the history of universal jurisdiction. Grotius had defended universal jurisdiction over "gross violations of the law of nature or of nations...." Other than piracy. Hugo Grotius, The Rights of War and Peace, A. C. Campbell (trans.), (M. Walter Dunne Publishing, Washington, 1901) p. 247, bk. II, ch. 20, § 40. The Jerusalem Court quotes this passage in Prosecutor v. Eichmann, District Court of Jerusalem, Criminal Case No. 40/61, Judgment (1961), para.14.

${ }^{42}$ Arendt, supra note 6, p. 262. She is referring to Article 6, which provides that either the territorial state where the genocide was committed or a competent international tribunal can try the crime of genocidewhich was, in fact, a weakened alternative to universal jurisdiction. Saudi Arabia, Lebanon, and Iran had proposed universal jurisdiction, but several powerful states opposed it and prevailed. William A. Schabas, Genocide in International Law: The Crime of Crimes, (Cambridge University Press, Cambridge, 2000) pp. 355-58.

${ }^{43}$ Prosecutor v. Eichmann, supra note 41, paras. 23-25.
} 
Israel could easily have claimed territorial jurisdiction if she had only explained that 'territory,' as the law understands it, is a political and a legal concept, and not merely a geographical term. It relates not so much, and not primarily, to a piece of land as to the space between individuals in a group whose members are bound to, and at the same time separated and protected from, each other by all kinds of relationships, based on a common language, religion, a common history, customs, and laws. ${ }^{44}$

True, there are examples in law of special territorial jurisdictions not tied to "a piece of land"- the most obvious is a ship on the high seas, which is in the territorial jurisdiction of its flag state. ${ }^{45}$ It is equally true that territorial jurisdiction is a legal rather than geographical concept. But declaring that territorial jurisdiction bears no essential connection to territory is farfetched. It is also unnecessary.

What Arendt had in mind was a connection entirely unique to the Jews and the state of Israel: she explains that "the Jewish people had ... created and maintained its own specific in-between space throughout the long centuries of dispersion, ${ }^{46}$ and apparently she believes that this is why the Jewish state could assert jurisdiction once it came into existence. The argument itself is not fanciful: in fact, the Jerusalem court used exactly this argument about the connection between Israel and the Diaspora to justify taking jurisdiction under the protective principle. ${ }^{47}$ The fanciful part is the claim that such jurisdiction is in any sense territorial.

To summarize: Arendt, in accord with Jaspers, believed that the grounds of jurisdiction suitable for international crime must be limited to those appropriate to crimes

\footnotetext{
${ }^{44}$ Arendt, supra note 6, pp. 262-63.

${ }^{45}$ For examples in U.S. law, see 18 U.S.C. $§ 7$.

${ }^{46}$ Arendt, supra note 6, pp. 263.

${ }^{47}$ Prosecutor v. Eichmann, supra note 41, paras. 34-35. Curiously, Arendt makes no mention of the protective principle as a possible source of jurisdiction.
} 
that offend against all humanity. On principle, the correct forum would therefore be an international tribunal; second best would be a national court exercising universal jurisdiction. Eventually Arendt rejected universal jurisdiction, but for weak reasons. Her argument for avoiding passive personality jurisdiction is stronger: passive personality "localizes" the crime to an offense against its victims, and therefore misses the sense in which the crime offends all of humanity, and in which a domestic court serves as a proxy for humanity rather than its own state's nationals.

\section{Genocide and Group Identity}

As I mentioned, EJ uses the terms "genocide” and "crimes against humanity" interchangeably, in disregard of significant differences in their legal definitions. One reason we have seen is that Arendt uses the term “crime against humanity” in a nontechnical way, to designate a crime that offends all of humanity.

She explains what she has in mind when she distinguishes the crimes of expulsion and genocide.

Expulsion of nationals ... is already an offense against humanity, if by "humanity" we understand no more than the comity of nations .... It was when the Nazi regime declared that the German people ... wished to make the entire Jewish people disappear from the face of the earth that the new crime, the crime against humanity-in the sense of a crime “against the human status,” or against the very nature of mankind-appeared ....

[Genocide] is an attack on human diversity as such, that is, upon a characteristic of the 
"human status” without which the very words "mankind” or "humanity” would be devoid of meaning. $^{48}$

At first glance, Arendt’s reference to "human diversity as such" makes her reasoning sound remarkably similar to Raphaël Lemkin’s argument for singling out genocide as a distinctive crime. For Lemkin, national or ethnic groups as such are essential to humanity, because they have value over and above the individuals who make them up. Lemkin emphasizes the contributions that members of different national groups have made to world culture: the Jews produced Einstein and Spinoza, the Poles Copernicus, Chopin, and Curie; the Czechs, Huss and Dvorak; the Greeks, Plato and Socrates; the Russians, Tolstoy and Shostakovich. ${ }^{49}$ Because Lemkin focused on the contributions of groups to civilization, he insisted that the law must protect groups by criminalizing the intentional effort to destroy a group (national, ethnic, racial, or religious) as such. That, of course, is precisely what the legal definition of genocide does, and its focus on intent to destroy groups "as such" is the feature that distinguishes genocide from the crime against humanity of extermination.

Contrary to the initial impression of similarity, though, Arendt's approach breaks sharply with Lemkin’s. Her own views about the value of groups have nothing to do with their cultural contributions, and indeed she finds the emphasis on geniuses belonging to minority groups morally repugnant. ${ }^{50}$ What she means by diversity is individual

\footnotetext{
${ }^{48}$ Arendt, supra note 6, pp. 268-69.

${ }^{49}$ Raphaël Lemkin, Axis Rule in Occupied Europe: Laws of Occupation, Analysis of Government, Proposals for Redress (Carnegie Endowment for International Peace, Washington, 1944) p. 91. The list is Lemkin's own.

${ }^{50}$ Arendt, supra note 6, pp. 132-34 (criticizing preferential treatment of Jewish elites). "There are more than a few people, especially among the cultural elite, who still publicly regret the fact that Germany sent
} 
uniqueness, not group diversity. In The Human Condition, she defines the key term "plurality” in individualist terms: "In man, otherness, which he shares with everything that is, and distinctness, which he shares with everything alive, becomes uniqueness, and human plurality is the paradoxical plurality of unique beings.” ${ }^{51}$ (Paradoxical, because Arendt also emphasizes human equality.) This is notably different from standard usage in American political science, where "pluralism” means group pluralism—a usage closer to Lemkin’s. Although in EJ she chooses the word “diversity” rather than "plurality,” she clearly means the same thing: both words designate the defining characteristic of humanity, which lies in the human condition of individual difference from all one's peers. ${ }^{52}$ In this connection, her earlier-quoted argument that trials must focus exclusively on the perpetrator, because only that turns him from a cog in a machine into a human being, turns out to be no exaggeration.

At this point it will be useful to examine Arendt's own views about identity groups and identity politics. She scorned romantic nationalism, which "holds a nation to be an eternal organic body, the product of inevitable natural growth of inherent qualities,” and which "explains peoples, not in terms of political organizations, but in terms of biological superhuman qualities." ${ }^{53}$ At bottom, she wholly rejects the communitarian thesis that attachments to groups give us our identity and creates pre-political obligations of loyalty. This rejection comes out most clearly in her exchange of letters about $E J$ with

Einstein packing, without realizing that it was a much greater crime to kill little Hans Cohn from around the corner, even though he was no genius.” Ibid., p. 134.

${ }^{51}$ Arendt, supra note 1, p. 176.

${ }^{52}$ Ibid., p. 175.

${ }^{53}$ Hannah Arendt, 'Zionism Reconsidered', in Jerome Kohn \& Ron H. Feldman, (eds.), Hannah Arendt, The Jewish Writings (Schocken, New York, 2007) pp. 343, 366-67. In a 1933 letter to Jaspers, she remarked that every use of a phrase like "the German character" "is almost identical with misuse." Arendt to Jaspers, Jan. 6, 1933, Kohler and Saner, supra note 4, p. 18. 
Gershom Scholem (the great scholar of Jewish mysticism). ${ }^{54}$ Scholem was deeply offended by Arendt's tone as well as her criticisms of the wartime Jewish leadership and the Israelis. He chided her for lack of “Herzenstakt”-i.e., lack of heart—and told her that, as "wholly a daughter of our people" she should have been more circumspect. ${ }^{55}$ "In the Jewish tradition there is a concept ... which we know as Ahabath Israel: 'Love of the Jewish people....",56 She responded:

I found it puzzling that you should write "I regard you wholly as a daughter of our people, and in no other way.” The truth is I have never pretended to be anything else or to be in any way other than I am, and I have never even felt tempted in that direction. It would have been like saying that I was a man and not a woman—-that is to say, kind of insane .... To come to the point: let me begin ....with what you call "love of the Jewish people” or Ahabath Israel ....You are quite right—I am not moved by any "love” of this sort ... : I have never in my life "loved” any people or collective—neither the German people, nor the French, nor the Americans, nor the working class or anything of that sort. I indeed "love" only my friends and the only kind of love I know of and believe in is the love of persons. ${ }^{57}$

Now in fact, Arendt's Jewish identification ran deep. She wrote extensively on Jewish affairs - her collected Jewish writings run more than 500 pages and span five decades. In France before the Occupation she worked for a Zionist organization, Youth Aliyah, and

\footnotetext{
${ }^{54}$ Scholem's letter and Arendt's are published together in Ron H. Feldman (ed.), The Jew as Pariah: Jewish Identity and Politics in the Modern Age (Grove Press, New York, 1978), now regrettably out of print. Scholem published his letter (without Arendt's) in On Jews and Judaism in Crisis: Selected Essays (Schocken, New York,1976) p. 300; and Arendt's letter (without Scholem's) appears in Kohn and Feldman, supra note 53, p. 465.

${ }^{55}$ Scholem to Arendt, June 23, 1963, in Feldman, supra note 54, pp. 241-42.

${ }^{56}$ Ibid., p. 241.

${ }^{57}$ Arendt to Scholem, July 24, 1963, ibid., p. 246; Kohn and Feldman, supra note 53, pp. 466-67.
} 
after the war she became executive director of Jewish Cultural Reconstruction, a nongovernmental organization that recovered a vast trove of Jewish books and cultural objects. ${ }^{58}$ Her commitment to the Jewish homeland was passionate, although her Zionism favored what would today be called a one-state solution-a Jewish homeland within a binational commonwealth, but not a Jewish state-a view that was more mainstream in the 1940 s than it is today, when it is a hallmark of anti-Zionism. ${ }^{59}$

In my view there is no contradiction between Arendt's outright denial that love of a people is a coherent concept and her own identity politics. Her views about group-based identity are philosophically subtle. Although she rejects group-based metaphysics, she nevertheless believes that describing our identity in terms of ethnicity may sometimes be politically necessary:

[F]or many years I considered the only adequate reply to the question, Who are you? to be: A Jew. That answer alone took into account the reality of persecution. As for the statement with which Nathan the Wise (in effect, though not in actual wording) countered the command: “Step closer, Jew”- the statement: I am a man—I would have considered as nothing but a grotesque and dangerous evasion of reality.

... When I use the word "Jew" I do not mean to suggest any special kind of human being .... Rather, I was only acknowledging a political fact through which my being a member of this group outweighed all other questions of personal identity or rather had decided them in favor of anonymity, of namelessness. Nowadays such an attitude would seem like a pose .... Unfortunately, the basically simple principle in question here

\footnotetext{
${ }^{58}$ Young-Bruehl, supra note 2, pp. 134, 143-44, 187-88.

${ }^{59}$ See her crucial essays in The Jewish Writings: 'Zionism Reconsidered', in Kohn and Feldman, supra note 53, pp. 343-74; 'The Jewish State: Fifty Years After, Where Have Herzl's Politics Led?', ibid., pp. 375-87; 'To Save the Jewish Homeland', ibid., pp. 388-401; and 'Peace or Armistice in the Near East?', ibid., pp. 423-50. While some of her concerns in these essays are dated (e.g., the possible Israeli turn toward the Soviet Union), others are eerily prophetic.
} 
is one that is particularly hard to understand in times of defamation and persecution: the principle that one can resist only in terms of the identity that is under attack. ${ }^{60}$

What Arendt is getting at, I think, is what might be deemed a political theory of ethnic identity. That is, utterances such as "I am a Jew” are not simply neutral descriptions, nor are they metaphysical statements that group affiliation constitutes individual identity. Rather, they are speech acts of alliance and confrontation.

Had Arendt, living in Paris in 1940, replied to the question, “Who are you?” by saying "I am a German” or "I am a human being,” she would have been hiding. The reply would have disowned other Jews, abandoned them to their fate, and let her questioner evade responsibility. By replying “I am a Jew," on the other hand, she would show her solidarity, as well as compel the questioner to acknowledge the Nazi persecution and situate himself in relation to it. When she arrived in America in 1941, she kept her birth name rather than taking her German husband’s “because I wanted my name to identify me as a Jew."61

Delivering a speech in Hamburg, in 1959, however, Arendt claims that to reply "I am a Jew” would just be a pose. And surely she is right-it would be cheap victimology, said only to make her German audience squirm. Differences in political situation define differences in the speech acts performed by ascriptions of ethnicity. Thus the utterance "I am a Jew” can be factually true, false as a statement about essence or identity ("when I use the word 'Jew' I do not mean to suggest any special kind of human being”), and politically indeterminate, performing entirely different speech acts depending on the

\footnotetext{
${ }^{60}$ Hannah Arendt, 'On Humanity in Dark Times: Thoughts About Lessing', in Men in Dark Times (Mariner Books, New York, 1968), pp. 17-18.

${ }^{61}$ Arendt to Jaspers, Jan. 29. 1946, in Kohler and Saner, supra note 4, p. 29.
} 
circumstances. Arendt claims that group identification becomes politically indispensable in circumstances of persecution because "one can resist only in terms of the identity that is under attack.” This is not an "essentialist” claim about groups constituting identity. Nor is it Lemkin’s claim about the value of groups "as such.”

Arendt is no liberal individualist. She notes approvingly that the Romans, “perhaps the most political people we have known, used the words 'to live' and 'to be among men’ ... as synonyms.”62 But she distinguished sharply between the human being as a political and a social animal. ${ }^{63}$ For Arendt, the significance of group identity lies in the group's participation in political action, not in its social affinities. That is why she defended Israel against one of the chief accusations of its pre-independence opponents, that Israel is an artificial construction. "A generation brought up in the blind faith in necessity—of history or economy or society or nature—found it difficult to understand that precisely this artificiality gave the Jewish achievements in Palestine their human significance.”64 All political constructions are artificial: they result from human action which imbues them with meaning. Their artificiality is the source of, not an objection to, their value. In Arendt's famous triad of human activities—labor, work, and action-it is the last, political action, that displays the basic human condition of plurality.

Her exalted view of politics explains Arendt's strange theory of territorial jurisdiction. Recall her assertion that territory refers not to a "piece of land" but to "the space between individuals in a group” where they fashion their common life. ${ }^{65}$ Arendt

\footnotetext{
${ }^{62}$ Arendt, supra note 1, p. 7.

${ }^{63}$ Ibid., pp. 22-28.

64 'Peace or Armistice in the Near East?', in Kohn and Feldman, supra note 53, p. 435. She also dismissed the accusation of colonialism: "The building of a Jewish national home was not a colonial enterprise in which Europeans came to exploit foreign riches with the help and at the expense of native labor.” Ibid., pp. 434-35. There were no riches in Palestine, and Jewish labor competed with "native labor."

${ }^{65}$ Arendt, supra note 6, p. 262.
} 
frequently invokes the concept of an in-between space (or, as she sometimes calls it, a “space of appearance”) as the location of politics. ${ }^{66}$ For her, human beings dwell first and foremost among each other, and any condition that establishes a political space where we act together and in each other's sight serves the function of geographical territory. Instead of invoking territorial jurisdiction, she should have proposed simply that shared politics should suffice to create legal jurisdiction for crimes that attack it. Israel's jurisdiction over Eichmann arose because of Israel's connection with the Jews and their political life, not because the Jews form an ethnic or religious group.

It follows that Arendt would strongly reject Lemkin's theoretical basis for defining separate crimes of genocide and extermination, namely the special value he assigned to groups "as such.” ${ }^{67}$ Groups have value only through the political life they create, which of course does not exclude their language, culture, religion, and customs. Given the value Arendt places on politics, it is safe to say that she would have likewise objected to the still-controversial exclusion of political groups from the list of protected groups in the legal definition of genocide; in an important sense, she would have argued that political groups are the only ones that have value "as such.”

\section{The Banality of Evil}

We come finally to the banality of evil, the signature concept of EJ. The phrase "banality of evil” appears only twice in Eichmann in Jerusalem—once, with no explication, in the text, and once in the subtitle. In 1971 Arendt explained that the phrase refers to

\footnotetext{
${ }^{66}$ See, e.g., Arendt, supra note 1, pp. 198-99 (on the polis as “space of action” or “space of appearance”).

${ }^{67}$ I agree with her. David Luban, 'Calling Genocide By Its Rightful Name: Lemkin’s Word, Darfur, and the U.N. Report’, 7 Chicago Journal of International Law (2006) pp. 303-20.
} 
no theory or doctrine but something quite factual, the phenomenon of evil deeds, committed on a gigantic scale, which could not be traced to any particularity of wickedness, pathology, or ideological conviction in the doer, whose only personal distinction was a perhaps extraordinary shallowness. However monstrous the deeds were, the doer was neither monstrous nor demonic, and the only specific characteristic one could detect in his past as well as in his behavior during the trial and the preceding police examination was something entirely negative: it was not stupidity but a curious, quite authentic inability to think. $^{68}$

In $E J$ she uses the final phrase with a significant addition: "inability to think, namely, to think from the standpoint of somebody else.” ${ }^{69}$ She elaborates the idea that thinking requires adopting multiple points of view in her late philosophy of mind, where she distinguishes this ability from intelligence, and connects thinking both with personal identity and with the capacity for moral judgment. ${ }^{70}$ Arendt's ideas are philosophically rich, but this is not the place to discuss them.

In the posthumously-published Life of the Mind, Arendt explains that our tradition attributes evil to any number of things: the pride of Lucifer, the resentment and selfloathing of Richard III, the envy of Cain, the weakness of Macbeth, the depraved hatred of Iago or Claggart, the covetousness and cupidity that we are told is the "root of all evil." ${ }^{71}$ In Eichmann she found none of these, only an inability to function without the

\footnotetext{
${ }^{68}$ Arendt, 'Thinking and Moral Considerations', supra note 24, p. 159.

${ }^{69}$ Arendt, supra note 6, p. 49. Emphasis in original.

${ }^{70}$ Arendt, 'Thinking and Moral Considerations', supra note 24, p. 182-87. This essay is the best introduction to Arendt's late moral psychology and moral philosophy-better, in my opinion, than Thinking, which is overloaded with intricacy. See also Hannah Arendt, Between Past and Future: Eight Exercises in Political Thought, rev. ed., (Viking Press, New York, 1968) pp. 220-21, 241, discussing Kant's conception of "enlarged mentality” as the foundation of political judgment.

${ }^{71}$ Hannah Arendt, The Life of the Mind, Part One: Thinking, one-volume ed., (Harcourt Brace, New York,1978) pp. 3-4.
} 
“clichés, stock phrases, adherence to conventional, standardized codes of expression and conduct" that "have the socially recognized function of protecting us against reality, that is, against the claim on our thinking attention that all events and facts make by virtue of their existence.”72 This is what she means by Eichmann’s inability to think.

It is unfortunate that Arendt waited to define "banality of evil,” EJ's most misunderstood phrase. Arendt's critics have variously supposed her to have meant that Eichmann was legally or morally innocent of his crimes (despite her insistence that Eichmann was "one of the greatest criminals of that period" "73); or that all of us are potential Eichmanns or just as guilty as Eichmann (despite her explicit statements to the contrary ${ }^{74}$ ); or that mass murder is banal, at least to refined intellectuals such as herself (despite the fact that she had devoted her career to thinking about little else); or that Eichmann's fault lay in stupidity (despite her elaborate efforts to distinguish thought from intellect and thoughtlessness from stupidity ${ }^{75}$ ).

Arendt always denied that she was writing "a theoretical treatise on the nature of evil"; she insisted that it was only a trial report, and that "when I speak of the banality of evil, I do so only on the strictly factual level ...."76 Perhaps this is why she neglected to define the term. In private correspondence with McCarthy, she reiterated that she had no

\footnotetext{
${ }^{72}$ Ibid., p. 4. She makes the same point on p. 177, and in Arendt, supra note 6, p. 287.

${ }^{73}$ Arendt, supra note 6, p. 288.

${ }^{74}$ Ibid., p. 296.

${ }^{75}$ Ibid., pp. 287-88; Arendt, supra note 71, pp. 13, 57. For examples of these misfired criticisms by two eminent historians, see Richard Wolin, Heidegger's Children: Hannah Arendt, Karl Löwith, Hans Jonas, and Herbert Marcuse (Princeton University Press, Princeton, 2001) pp. 55-56; Tony Judt, 'At Home in This Century', New York Review of Books, April 6, 1995, p. 10.

${ }^{76}$ Arendt, supra note 6, pp. 285, 287. See also Arendt, supra note 71, p. 3. The term "trial report" is in Arendt, supra note 6, p. 280.
} 
“ideas” in EJ, only "a faithful description of a phenomenon.”77 In her 1964 postscript to $E J$, she describes her book as "simple reporting." 78

These claims are disingenuous. The fact is that well before she first saw Eichmann at the trial, she wrote Jaspers about Eichmann’s "bizarre vacuousness."79 More importantly, the idea that some perpetrators of great evil are conventional people without monstrous motives was not new to Arendt. As early as 1945, she described

the characteristic personality of the man who can boast that he was the organizing spirit of the murder. Heinrich Himmler is not one of those intellectuals stemming from the dim No Man’s Land between the Bohemian and the Pimp, whose significance in the composition of the Nazi élite has been repeatedly stressed of late. He is neither a Bohemian like Goebbels, nor a sex criminal like Streicher, nor a perverted fanatic like Hitler, nor an adventurer like Goering. He is a "bourgeois" with all the outer aspect of respectability, all the habits of a good paterfamilias who does not betray his wife and anxiously seeks to secure a decent future for his children .... ${ }^{80}$

Furthermore, the phrase may have originated with Jaspers, not Arendt. In 1946 Jaspers wrote her that rather than attributing demonic power to Nazism, "we have to see these things in their total banality, in their prosaic triviality, because that's what truly characterizes them. Bacteria can cause epidemics that wipe out nations, but they remain

\footnotetext{
${ }^{77}$ Arendt to McCarthy, Sept. 20, 1963, Brightman, supra note 2, p. 148; Arendt to McCarthy, Oct. 3, 1963, in ibid., p. 152.

${ }_{78}^{78}$ Arendt, supra note 6, p. 287.

79 "I would never be able to forgive myself if I didn’t go and look at this walking disaster face to face in all his bizarre vacuousness.” Arendt to Jaspers, Dec. 2, 1960, in Kohler and Saner, supra note 4, pp. 409-10.

Only a few days into the trial, she fulminated to her husband that a statement of Eichmann's was "so damned banal...”” Arendt to Heinrich Blücher, April 20, 1961, in Kohler, supra note 21, p. 357.

${ }^{80}$ Hannah Arendt, 'Organized Guilt and Universal Responsibility', in Jerome Kohn (ed.), Essays in Understanding 1930-1954 (Houghton Mifflin Harcout, New York, 1993) p. 128.
} 
merely bacteria." ${ }^{81}$ It seems entirely plausible that Jaspers’s phrase stuck in Arendt's memory. She used similar imagery in her letter to Scholem: evil "possesses neither depth nor any demonic dimension. It can overgrow and lay waste the whole world precisely because it spreads like a fungus on the surface.” ${ }^{82}$ Far from being an untheoretical observation, the idea that evil lacks depth has a long philosophical pedigree. It echoes St. Augustine, about whom Arendt wrote her Ph.D. thesis: Augustine wrote that seeking a cause for evil “is like trying to see darkness or to hear silence," because evil "is not a matter of efficiency, but of deficiency; the evil will itself is not effective but defective.” ${ }^{83}$ The banality of evil likewise has obvious echoes of her teacher Heidegger's discussion of “everydayness” in Being and Time. ${ }^{84}$

That does not make the banality of evil a mere philosophical speculation, however. Decades of research in experimental social psychology confirm that ordinary, non-monstrous people will do monstrous things - apparently without perceiving the monstrosity_in situations where role, authority, or peer pressure demand it. ${ }^{85}$ If anything, Arendt's insights into the banality of evil should by now be regarded as solidly

\footnotetext{
${ }^{81}$ Jaspers to Arendt, Oct. 19, 1946, in Kohler and Saner, supra note 4, p. 62.

${ }^{82}$ Arendt to Scholem, in Kohn and Feldman, supra note 53, p. 471. Arendt's image is more accurate than Jaspers's: she notices that a fungus on the surface can lay the world to waste without penetrating to the depth of Jaspers's "bacteria that wipe out nations."

${ }^{83}$ St. Augustine, City of God (Henry Bettenson (trans.), (Penguin, London, 1984) p. 480, 12.7; ibid., p. 473, 12.2.

${ }^{84}$ Martin Heidegger, Being and Time, John Macquarrie and Edward Robinson (trans.), (Harper, New York, 1962) pp. 149-69, sections 25-27.

${ }^{85}$ These include the famous Milgram and Stanford Prison experiments, but also many others in the "situationist" tradition of experimental psychology. See, e.g., Lee Ross and Richard E. Nisbett, The Person and the Situation: Perspectives of Social Psychology (Temple University Press, Philadelphia,1991); Philip Zimbardo, The Lucifer Effect: Understanding How Good People Turn Evil (Random House, New York, 2007).
} 
empirical, not philosophical (although whether Eichmann himself fit the diagnosis or simply fooled Arendt is a different question). ${ }^{86}$

The "banal” perpetrator is, at bottom, a moral chameleon whose values conform themselves to their environment. Lacking “an unequivocal voice of conscience, „ ${ }^{87}$ he equates right with normal and wrong with exceptional. ${ }^{88}$ In a decent polity, this confusion generally stands him in good stead. Disaster results when a criminal regime turns morality upside down and inverts ordinary legal rules and exceptions. Those are the circumstances in which everyday banality transmutes into the banality of evil. In Arendt's account, the banality of evil and state criminality fit together as cognate concepts. $^{89}$

The question is what legal significance the banality of evil has. One possible answer is that it has no significance: banality of evil refers to the perpetrator's motives, and motives are irrelevant in criminal law. Mens rea deals with intent and knowledge, not motive, and nobody suggested that Eichmann acted unintentionally or lacked knowledge of what he was doing or the consequences to his victims. Arendt asserts that "in all modern legal systems ... intent to do wrong is necessary for the commission of a crime.”90 But, a lawyer might object, this assertion misstates the requirements of mens rea, which include knowledge that an act is wrongful (in the sense of unlawful) only for a

\footnotetext{
${ }^{86}$ Eichmann's interrogator, Israeli captain Avner Less, thought Eichmann was a desperate liar. Johen von Lang (ed.), Eichmann Interrogated: Transcripts from the Archives of the Israeli Police, Ralph Manheim (trans.), (Da Capo Press, Cambridge MA,1983), at vi-vii. See also Abigail L. Rosenthal, A Good Look at Evil (Temple University Press, Philadelphia,1987) p. 167.

${ }^{87}$ Arendt, supra note 6, p. 148.

${ }^{88}$ Ibid., pp. 148, 293.

${ }^{89}$ Taking off from her analysis, I argue that international criminal law ought to broaden its scope to include criminal states and regimes as well as criminal individuals. David Luban, 'State Criminality and the Ambition of International Criminal Law’, in Tracy Isaacs and Richard Vernon (eds.), Accountability for Collective Wrongdoing, (Cambridge University Press, Cambridge, forthcoming).

${ }^{90}$ Arendt, supra note 6, p. 277.
} 
subset of crimes_-generally either purely regulatory (mala prohibita) offenses, or those specific intent (dolus specialis) crimes whose statutes specify knowledge of the act's illegality as an element. As for intent to do moral wrong or knowledge that one's act is morally wrong, neither are legal requirements for criminal conviction, and neither belongs to the legal concept of mens rea.

On the other hand, consider the defense of superior orders and mistake of law in the Rome Statute. It relieves a defendant of liability if: (1) the defendant was ordered to commit the crime and lay under a "legal obligation to obey" the order; (2) the defendant “did not know that the order was unlawful”; and (4) “[t]he order was not manifestly unlawful.” ${ }^{91}$ Eichmann had his orders, and to his knowledge they were legally obligatory under the Nazi doctrine Führerworte haben Gesetzeskraft-for no one doubted that Hitler ordered the Final Solution. ${ }^{92}$ Were the orders “manifestly unlawful”? The answer is obviously yes-in a normal environment. But in an upside-down system, where every responsible person in Eichmann's chain of command enthusiastically supported mass murder, and where the resources of the state were conspicuously devoted to it, in what sense is the unlawfulness of mass murder "manifest”? Article 33 completely evades this uncomfortable question by stipulating that "orders to commit genocide or crimes against humanity are manifestly unlawful."93 A stipulation is no answer. Arendt is clearly correct that the "plausibility" of such an answer "rests on the assumption that the law expresses

\footnotetext{
${ }^{91}$ UN Diplomatic Conference on Plenipotentiaries o the Establishment of an International Criminal Court, (U.N. Doc. A/Conf. 183/9 ${ }^{\text {th }}$ )[the Rome Statute of the International Criminal Court], art. 33 (titled "Superior orders and prescription of law"). Article 32 of the same statute provides that mistake of law can be a defense under the conditions of Article 33.

${ }_{92}$ Arendt, supra note 6, pp. 24, 128.

${ }^{93}$ Rome Statute, supra note 91, art. 33(2).
} 


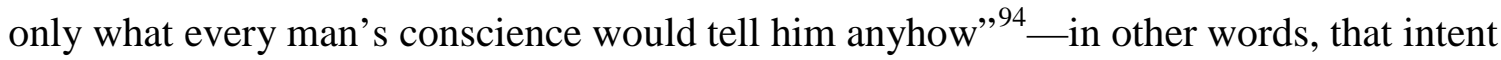
to commit these acts is intent to do wrong.

This is the biggest challenge that Arendt poses to international criminal law. When faced with a criminal state, and "banal” perpetrators who recognize evil only when it deviates from prevailing norms, the basis for criminal punishment must somehow be severed from subjective mens rea.

This perhaps explains Arendt's preoccupation with the hostis generis humanii. Eichmann may have lacked subjective awareness of guilt, but that made him no less the enemy of humanity. "Because he had been implicated and played a central role in an enterprise whose open purpose was to eliminate forever certain 'races' from the surface of the earth, he had to be eliminated." ${ }^{95}$ Unfortunately, the label hostis generis humanii creates as many problems as it solves—not least Schmitt's concern that it makes the perpetrator "a monster who must not only be defeated but also utterly destroyed." Arendt never came up with a satisfactory conception of objective culpability, nor did she claim to. In the Eichmann case, she believed that the Jerusalem judges "really passed judgment solely on the basis of the monstrous deeds” rather than the legal standards and precedents they cited in their opinion. ${ }^{97}$ In her eyes, this was a good thing. ${ }^{98}$ But that is a

\footnotetext{
${ }^{94}$ Arendt, supra note 6, p. 293; see also p. 148.

${ }^{95}$ Ibid., p. 277.

${ }^{96}$ Schmitt, supra note 25, p. 36. Cicero wrote in De Officiis that "we have no ties of fellowship with a tyrant, but rather the bitterest feud ... [T] hose fierce and savage monsters in human form should be cut off from what may be called the common body of humanity.” Cicero, supra note 40, p. 299, III.vi.32.

${ }^{97}$ Arendt, supra note 6, p. 294.

${ }^{98}$ Arendt's major preoccupation in the last decade of her life was an analysis of judgment and the central place it occupies among our mental and moral faculties. At Arendt's death, the title page with epigraphs of her unwritten book on judgment, the capstone of her trilogy on the life of the mind, was in her typewriter.
} 
troubling thought for jurists, who mistrust "kadi justice” that passes judgment freely on the facts. ${ }^{99}$ Jurists know that legal tools are the only ones they possess.

Notwithstanding her complaint that the court buried the unprecedented under a flood of precedents, Arendt knew it too, and she understood that no court can simply bypass eight hundred years of criminal jurisprudence linking culpability with mens rea. In the sole passage in EJ where she explains the basis of Eichmann's culpability in the absence of subjective awareness of wrongdoing, she writes:

\begin{abstract}
We refuse, and consider as barbaric, the propositions "that a great crime offends nature, so that the very earth cries out for vengeance; that evil violates a natural harmony which only retribution can restore; that a wronged collectivity owes a duty to the moral order to punish the criminal” (Yosal Rogat). And yet I think it is undeniable that it was precisely on the ground of these long-forgotten propositions that Eichmann was brought to justice to begin with, and that they were, in fact, the supreme justification for the death penalty. ${ }^{100}$
\end{abstract}

There is a striking ambivalence in this passage. As we saw, Arendt's critique of culpability resting on subjective mens rea drives her (and us) toward these "longforgotten propositions," and the final words in the passage make it sound as though she accepts them as "supreme justification” for the verdict. On the other hand, we "refuse, and consider as barbaric" those very propositions. ${ }^{101}$ When she summarizes her

\footnotetext{
99 "We do not sit like a kadi under a tree, dispensing justice according to considerations of individual expediency.” Terminiello v. Chicago, 337 U.S. 1, 11 (19)(Frankfurter, J. dissenting).

${ }^{100}$ Arendt, supra note 6, p. 254.

${ }^{101}$ Of course "the very earth cries out for vengeance" comes from God's words to Cain in Genesis 4:10, "your brother's blood cries out from the earth."
} 
complaints about the Eichmann trial, they are at bottom legal complaints, not complaints about legality:

In sum, the failure of the Jerusalem court consisted in its not coming to grips with three fundamental issues, all of which have been sufficiently well known and widely discussed since the establishment of the Nuremberg Tribunal: the problem of impaired justice in the court of the victors; a valid definition of the "crime against humanity"; and a clear recognition of the new criminal who commits this crime. ${ }^{102}$

Comparing Arendt's initial enthusiasm for the Eichmann trial in her first letter to Jaspers with the far more subdued postscript to $E J$, it seems clear that she had become chastened watching the trial unfold. Perhaps she could not decide whether the problem was a remediable defect in the Jerusalem proceedings or a fundamental mismatch between the law and the crime. All the questions she asked remain with us today, and they remain the biggest questions international criminal law must answer. ${ }^{103}$

\footnotetext{
${ }^{102}$ Ibid., p. 251.

${ }^{103}$ I am grateful to Allegra Macleod for the reading of Arendt expressed in the final paragraphs.
} 